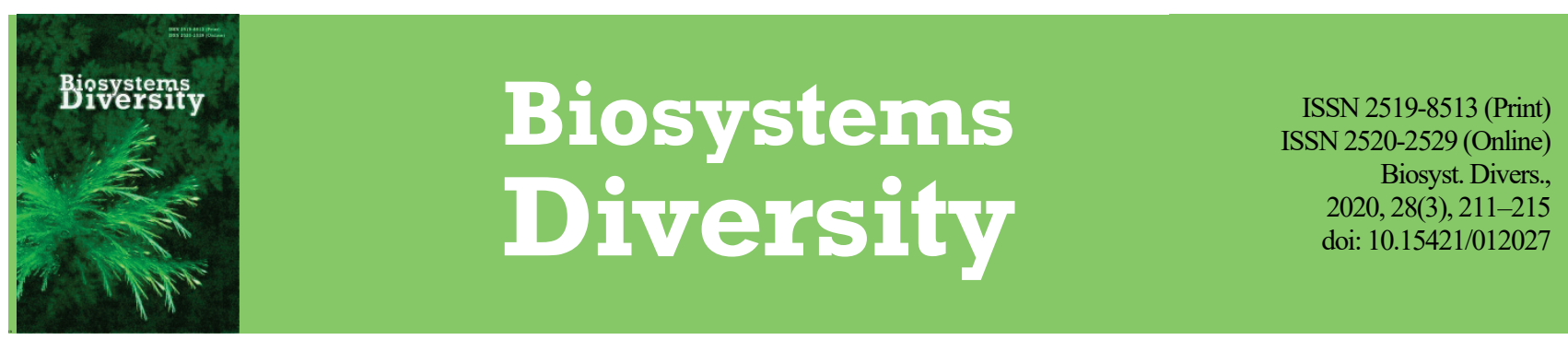

\title{
Iris sibirica (Iridaceae) on the territory of Western Ukraine
}

\author{
K. I. Scrypec, L. O. Tasenkevich, M. M. Seniv \\ Ivan Franko National University of Lviv, Lviv, Ukraine
}

Article info

Received 15.07.2020

Received in revised form 17.08 .2020

Accepted 20.08.2020

\section{Scrypec, K. I., Tasenkevich, L. O., \& Seniv, M. M. (2020). Iris sibirica (Iridaceae) on the territory of Western Ukraine. Biosystems Diversity, 28(3), 211-215. doi:10.15421/012027}

Ivan Franko National

University of Lviv,

Hrushevsky st., 4 ,

Lviv, 79005, Ukraine.

Tel.: +38-097-177-04-70.

E-mail:

xrustysja-skrypec@ukr.net

The state of Iris sibirica L. in the national botanical reserve "The Valley of the Irises" is characterized. In particular, it was found that I. sibirica should be classified in the group of Euro-West Siberian, and not as a Euro-Siberian or even Eurasian species. Phenological rhythms and peculiarities of fruiting have been studied. It is established that the duration of the vegetation period of I. sibirica lasts 187-246 days. The most important stages of the reproductive cycle of I. sibirica (structure of inflorescences, flowers, fruits and seeds, phenology, seed productivity) have been studied. We first discovered that on the inner surface of the flower tube there is a multilayer secretory tissue - perigonal nectar. The fruiting of I. sibirica, which lasts quite a long time: 2-3 months (6080 days) from June to August, was studied. In this population two ways opening of the capsule were observed. Apis mellifera (Linnaeus, 1758) (honey bee) and Bombus bombus (Latreille, 1802) (bumblebee) are pollinators of I. sibirica in the reserve. The coefficient of seed productivity of I. sibirica was high and quite stable, but despite the high potential and actual seed productivity in the population there is a weak seed recovery, which is associated with high turfing and invasions of members of the phytophagous genus Ceutorhynchus. Their activity dramatically reduces the maturation and dissemination of full-fledged mature seeds due to damage to flowers, capsules and seeds in them. However, the population of I. sibirica in the "The Valley of the Irises" is mature, normal, with a slight predominance of young individuals, which provides it with positive dynamics.

Keywords: inflorescences; flowers; fruits; seeds; phenology; population; seed productivity.

\section{Introduction}

The genus Iris Tourn. ex L. (Iris), which belongs to one of the most species-rich families in the class Monocotyledoneae - Iridaceae Juss., according to various sources, is represented in the world flora by from 250 (Mathew, 1981; Goldblatt \& Manning, 2008) to 362 species and 16 subspecies (www.theplantlist.org).

In Ukraine, according to the latest list, there are 16 known taxa (Mosyakin \& Fedoronchuk, 1999). The Red Book of Ukraine included only three of these taxa in 1996 - Iris pontica Zapał., I. pineticola Klokov, I. pseudocyperus Schur (Shelyag-Sosonko, 1996). In addition to the three mentioned, the third edition of the Red Book of Ukraine also includes I. furcata M. Bieb. and I. sibirica L. (Didukh, 2009).

All available data (herbarium collections, literature sources and the results of her own field research) on the distribution of these species were collected and analyzed in detail by Zhigalova (2012). The author came to the conclusion that the number of localities not only of rare and endangered species of the genus, but also of its widespread representatives, such as I. pseudacorus L., is declining (Zhigalova, 2014). However, the finding of a new population of I. pseudacorus in the steppe zone on the banks of the Luhansk River (Kharchenko, 2014) indicates that chorological studies of the genus Iris in Ukraine have not been completed.

Especially, this applies to their rare representatives, in particular $I$. sibirica. Thus, in Chernihiv Polissya, where, compared to other regions, there is a significant concentration of loci (over 30) of this species (Lukash, 2010; Podorozhny, 2012), a new locality of I. sibirica was found in the Dnipro-Desna interfluve (Shynder, 2013). In Chernivtsi region, of 20 previously known localities of I. sibirica only three were found by the authors to support this species (Tokaryuk et al., 2017). And the very recent finding of a large plot (20 hectares) in the Mykolayiv district of Lviv region came as a real surprise (Seniv \& Tasenkevych, 2017).

Since the main studies of I. sibirica in Ukraine were conducted mainly on population level, the aim of our work was to study the most important stages of the reproductive cycle (structure of inflorescences, flow- ers, fruits and seeds, phenology, seed productivity), detect the major pests, reveal population density depending on microrelief conditions.

\section{Materials and methods}

The study was conducted in 2017-2019 on a population of I. sibirica in the vicinity of Naditychi, Mykolaiv district, Lviv region, on the floodplain terrace of the Dnister River, on a wet swampy meadow near the railway track (national botanical reserve "The Valley of the Irises "). Since the species is listed in the Red Book of Ukraine (Melnyk et al., 2009), the material was collected in the minimum amount required for the study.

The collected materials were fixed in a Chamberlain retainer. Microscopic examination was performed using a light microscope XS-2610 (PRC) and binocular microscope MBS-10, photographs were taken using a photography camera CANON IXUS 9515. Evaluation of seed productivity and population density was performed according to the method developed by Zlobin (2013) for 10 replicates. Phenological observations were performed according to the method of Beidemann (1974). Periodization of fruiting was studied according to the method of Levina (1963, 1967, 1970).

\section{Results}

On the territory of the reserve the inflorescence of I. sibirica produces a small-flowered (1-3 flowers ) fan-shaped monochasium which is characterized by significant morphological polyvariance in number of flowers, their location in partial inflorescences and flowering order. Examining the population, we found that two-flowered and three-flowered inflorescences make up about $30 \%$, four-flowered inflorescences about $15 \%$ and the least, six-flowered $-5 \%$ of inflorescences. In general, we found about $70 \%$ of five-flowered inflorescences.

The flowers in this population of I. sibirica are dark purple and pale purple (albino), large, 5-8 cm in diameter, apical, full, bisexual, threemembered, actinomorphic, with a lower ovary, on a long peduncle 
(Fig. 1a). Examining the morphological structure of the flower, we found that the leaves of the perianth and stamens grow into a goblet-shaped inflated perianth tube 1.0-1.5 cm long (Fig. 2a). Examining the anatomical structure of the inner surface of the flower tube, we found a multilayered secretory tissue. The secretory epidermis of the nectar is represented by papillary cells with a thickened cuticle. The subepidermal layer of the nectar is small-celled with a dense cytoplasm, enriched with numerous small conducting bundles; such a nectar should be defined as perigonal mesophilic.

Palynological studies have revealed four types of pollen grain shapes: (1) broad- or (2) narrowly elliptical, (3) more or less narrowed to the tips, (4) sometimes elongated-pointed, with a wide seedling groove on the distal side of the grain. The size of pollen grains varies widely -17.3 $23.8 \mu \mathrm{m}$.

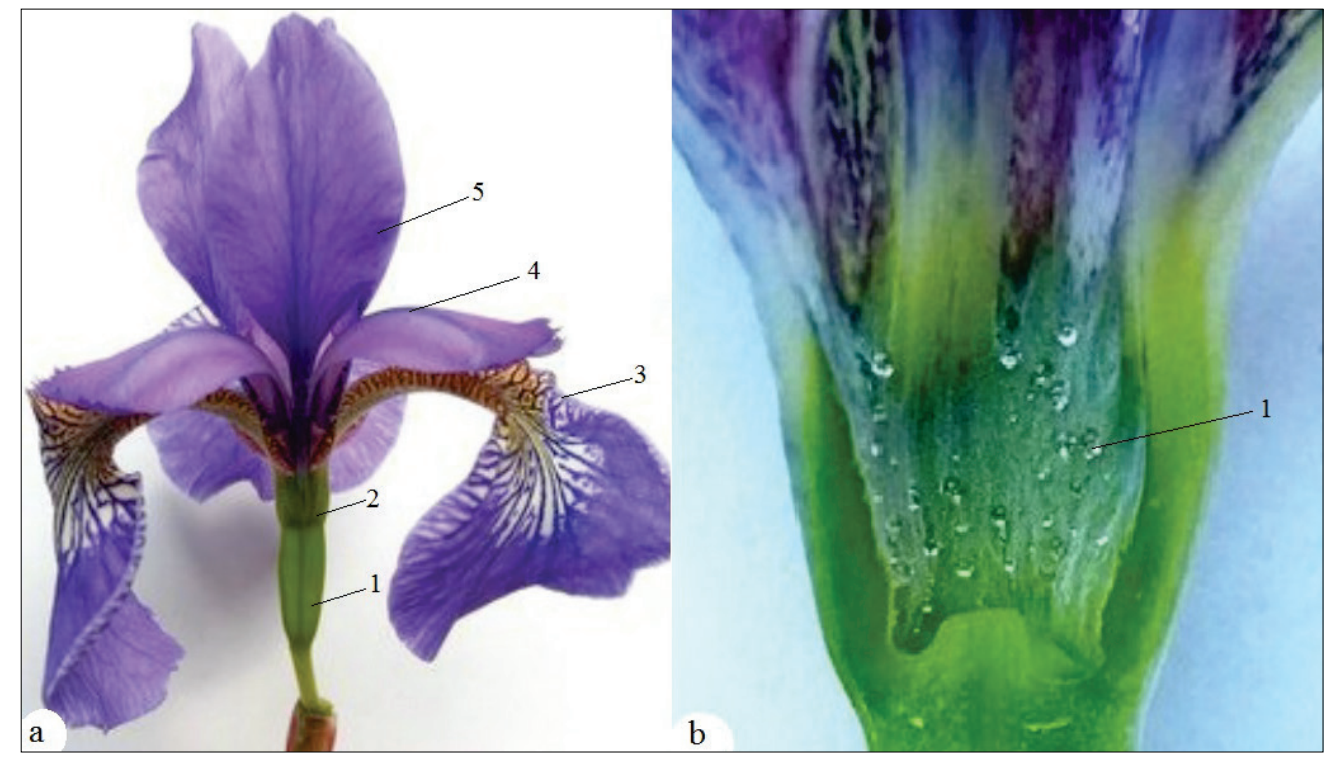

Fig. 1. Opened flower of $I$. sibirica (a): 1 - flower wreath, 2 - perianth tube, 3 - outer leaves of perianth, 4 -stylodium, 5 -inner leaves of perianth; longitudinal section through the the perianth tube $(b): 1$ - perigonal nectar

The I. sibirica fruit is a oblong-oval capsule, triangular at the apex, without a spout. The average length of the fruit is $26 \mathrm{~mm}$, the diameter of the mature fruit is $14 \mathrm{~mm}$. The size of the fruit depends on the number of seeds that ripen in the fruit. The number of seeds in one capsule can range from 7 to 206. The colour of the fruit at the beginning of fruiting is green, in the middle of fruiting - yellow, and at the end of fruiting - dark brown. The number of seed germs ranges from 222 to 340 . The length of $I$. sibirica seeds is $4.6-4.8 \mathrm{~mm}$ and width $3.6 \mathrm{~mm}$. The weight of 100 seeds varies in the range $0.17-0.19 \mathrm{~g}$, in $1 \mathrm{~g}$ there are $11-14$ pieces.

On the territory of the botanical reserve of national importance "The Valley of the Irises" we observed two ways of fruit opening. The first method is the opening along the dorsal vein, which is incomplete, often does not reach half the length of the ovary, and in low-seeded fruits barely reaches $1 / 4$ the length of the fetus. As a result of the divergence of the wings, the seeds in the upper part of the fetus are detached from the placenta and poured out. In the lower part of the fruit, the seeds remain in the nests of the ovary and fall out of them only when shaken. Often the seeds from the lower half of the capsule remain in it until the lodging and rot of generative shoots.

The second type of opening which we discovered is in the fruit, in which dorsal opening sutures are formed in the middle part of the fruit, and at the base and at the top they do not appear. The wings of the fruit do not diverge, but remain firmly connected to the central column, as a result of which the seeds are exposed from the capsule due to only one dorsal gap.

In the population of I. sibirica, we observed buds and flowers severely damaged by Acklandia servadeii (Séguy, 1933) (an iris fly) that winters in the soil and emerges in early spring to lay eggs in green buds. As a result, larvae hatch from the eggs, feed on the tissues of the buds and lay their excrement there. The bud inside begins to rot, and its perianth dries up. Flowers never bloom from such a bud.

In the fruits we found Mononychus punctumalbum (Herbst, 1784) (weevil), which lives near water bodies. Development occurs in the capsules of individuals of the genus Iris. Females lay eggs in the spring. The larvae develop quite rapidly and from late July to early September there is a new generation of adult $M$. punctumalbum. The bugs overwinter in the litter at the adult stage. It is established that the duration of the vegetation period of I. sibirica lasts 187-246 days. The growing season in the population begins with the formation of the first leaves and ends with their fall (Fig. 2). For I. sibirica the growing season strongly depends on weather conditions. Vegetation begins with the transition of average daily temperatures through the mark of $+5{ }^{\circ} \mathrm{C}$, after which the curtain forms the first leaves 10-20 cm tall (Fig. 2a). Full leafing occurs with the formation of the curtain with leaves 70-100 cm tall (Fig. 2b). Budding in the population lasts 10-30 days, starting from the third decade of April to the third decade of May. Budding begins with the appearance of peduncles, which are formed in the axils of the leaves (Fig. 2c). Flowering of the population lasts 15-40 days - from the first decade of May to the third decade of June (Fig. 2d). The beginning of flowering occurs when the first bud is opened.

Fruiting of $I$. sibirica lasts a long time: $2-3$ months (60-80 days), from June to August (Table 1). This period for one individual coincides in duration with the stage of budding and flowering. The beginning of fruiting is recorded by the fall of the perianth in the first flower, which occurs 7-10 days after wilting. During fruiting, the fruits change colour from green to yellow, then - to brown and black (Fig. 2e). Mass fruiting lasts 10-15 days. The end of fruiting, which was recorded by the fall of seeds into the soil, is in the second decade of August (Fig. 2f).

Table 1

Periodization of fruiting in Iris sibirica in 2017-2019

\begin{tabular}{lc}
\hline \multicolumn{1}{c}{ Periods } & Duration, days \\
\hline Duration of fruiting & $60-80$ \\
Perianth wilting & $7-10$ \\
Perianth precipitation & 1 \\
Mass fruiting & $10-15$ \\
Browning of the fetus & $10-15$ \\
Opening of a fruit & 10 \\
\hline
\end{tabular}

The average number of fruits per generative shoot in the study population ranges 2.2-3.0. The average number of seeds per generative shoot ranges 159-232, and the average number of seed germs per generative shoot $-222-340$ pieces. The research results showed that the actual seed productivity is 71.7 pieces per capsule and the potential seed productivity is 106.6 pieces (Table 2). The coefficient of I. sibirica seed productivity, which characterizes the viability of the species in specific habitat conditions was high and fairly stable. Its values range from $66,8 \%$. 


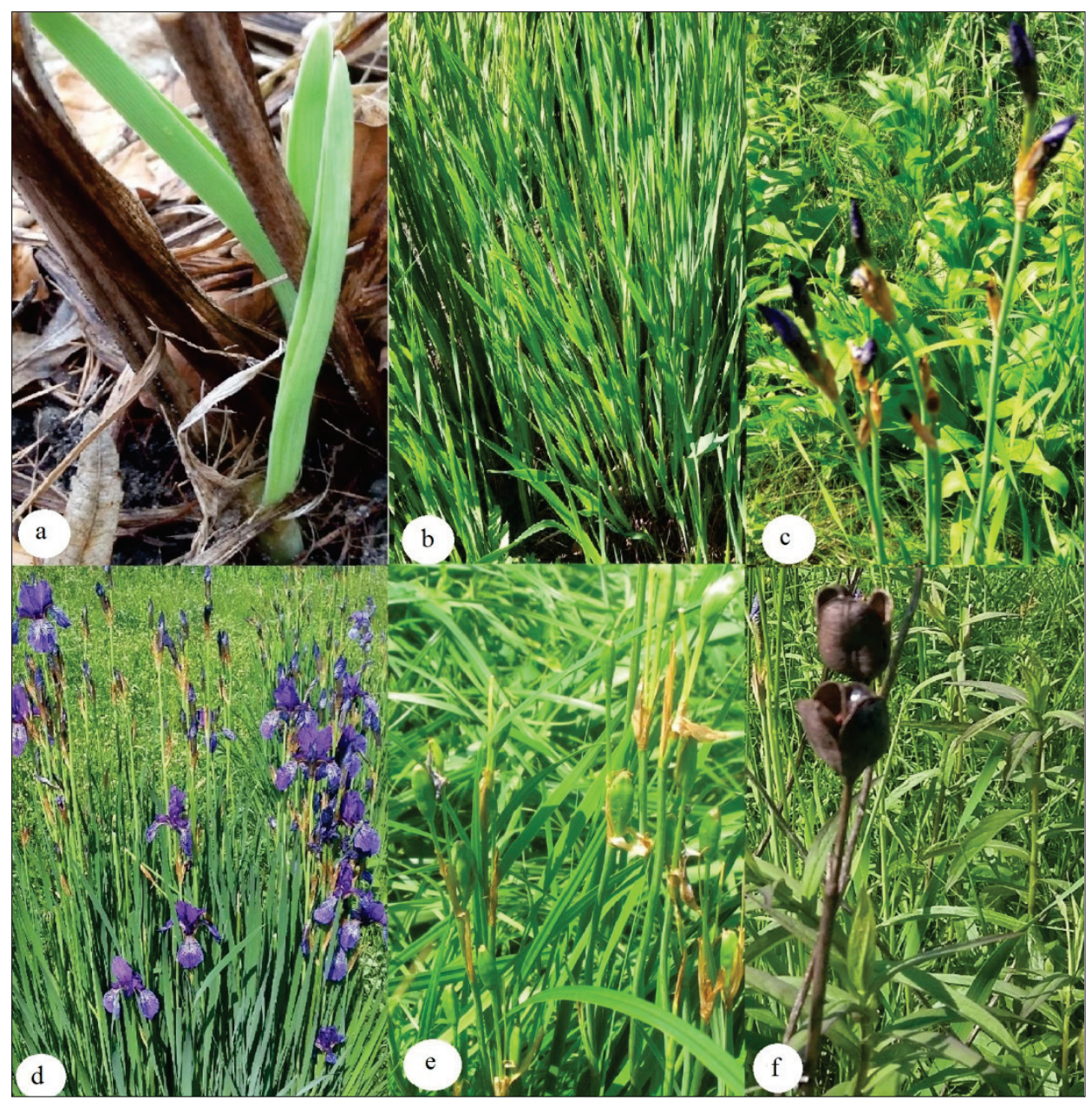

Fig. 2. Phenophases of $I$. sibirica 2017-2019: $a$-beginning of vegetation, $b$-complete leafing, $c$-budding, $d$-flowering, $e$-fruiting, $f$-dissemination

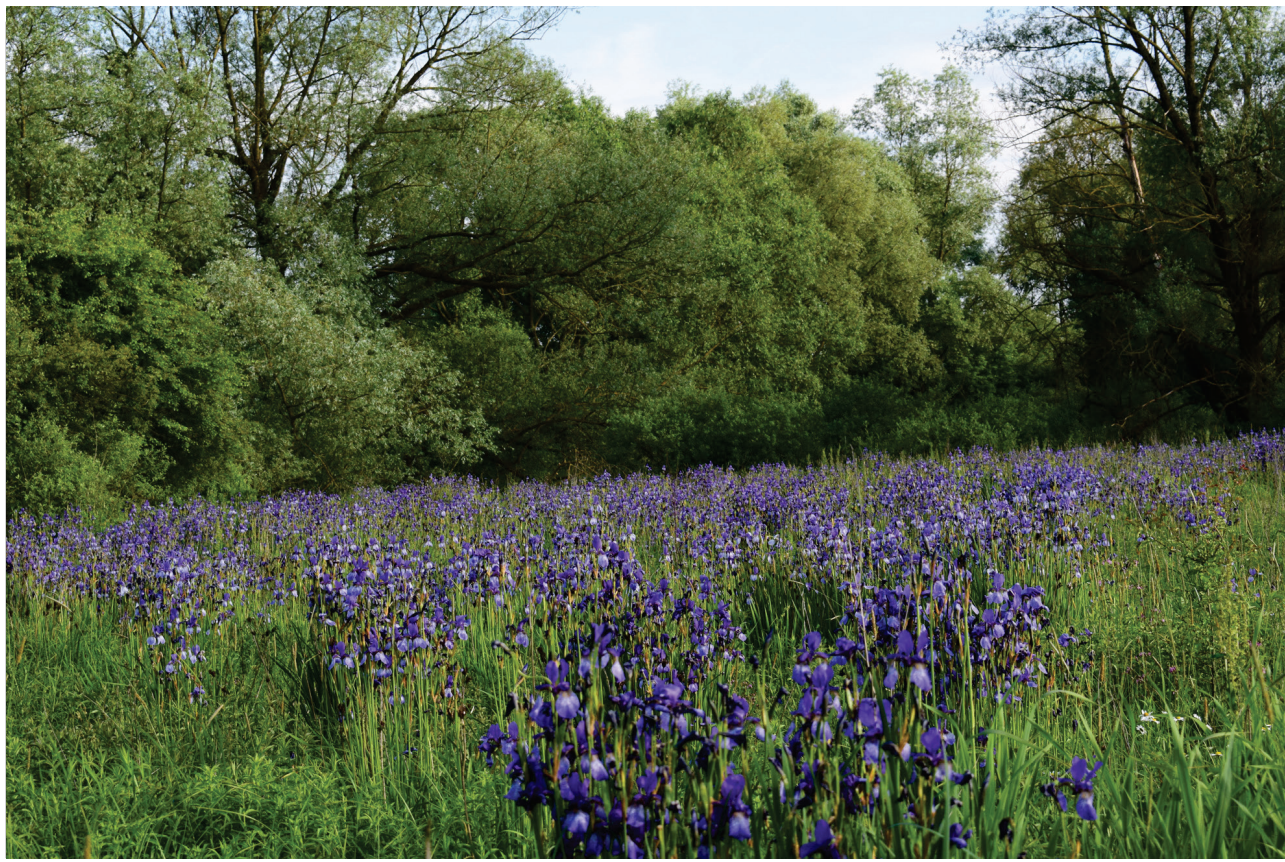

Fig. 3. Population density of $I$. sibirica in the plot 1 of the botanical reserve of national importance "The Valley of the Irises"

Since the territory of the botanical reserve consists of five plots with a total area of 20 ha, to study the population density we chose plot 1 as the main area, which is 13.8 ha in size (Fig. 3).

In this area, the species forms various mature clones (up to 50 generative shoots per individual in the adult mature state), gives significant selfseeding. Reproduction occurs both by seed and vegetatively. The area of the population is heterogeneous and we found places with fairly old clones, which have a density of 54 individuals per $100 \mathrm{~m}^{2}$, and the number of generative shoots from 401 to 705 per $100 \mathrm{~m}^{2}$. The main part of the area is formed by relatively young individuals, with a much higher density from 92 to 150 individuals per $100 \mathrm{~m}^{2}$, respectively, and the number of shoots ranges from 8 to 1172 per $100 \mathrm{~m}^{2}$. 
Table 2

Indicators of $I$. sibirica seed productivity 2017-2019 $(\mathrm{x} \pm \mathrm{SD}, \mathrm{n}=10)$

\begin{tabular}{lc}
\hline \multicolumn{1}{c}{ Indicators } & Average value \\
\hline Potential seed productivity, pcs. & $106.6 \pm 2.4$ \\
Actual seed productivity, pcs. & $71.7 \pm 3.5$ \\
Coefficient of seed productivity, $\%$ & 0.668 \\
\hline
\end{tabular}

Note: coefficient of seed productivity $=$ actual seed productivity / potential seed productivity.

\section{Discussion}

I. sibirica is widespread in Europe: in France, in the north of Italy, in Switzerland, Austria, the Czech Republic, Slovakia, Germany, Hungary, Poland, Romania, Bulgaria, the countries of former Yugoslavia, in the north of Turkey, in Belarus, Estonia, Latvia, Lithuania Moldova, Ukraine, the European part of the Russian Federation; in Asia: Armenia, Azerbaijan, northwestern Kazakhstan, and southwestern Western Siberia (Tsvelev, 1979; Webb, 1980; Doronkin, 1987).

In some European publications (especially domestic ones, including the latest edition of the Red Book of Ukraine), which describe I. sibirica, the authors mistakenly include Eastern Siberia, the Far East, Japan, Mongolia, China and Korea in its range. In these areas, a completely different species is common - I. sanguinea Donn ex Hornem. (Doronkin, 1987; Yutang et al., 2000), which can be seen in the publication of Meusel et al. (1965). For this reason, the area of I. sibirica should be classified as EuroWest Siberian, and not as Euro-Siberian or even Eurasian type.

In Ukraine the species is widespread in Transcarpathia, Prykarpattia, Transnistria, Opillia and Roztocze, Male Polissya, in the west of Podilla Upland, in Polissya, in the Forest-Steppe zone, occasionally in the northern part of the Steppe. According to Podorozhny (2010), I. sibirica was recorded on the Demerdzhi Yayla and on the border of the Dovhorukivska and Tyrke Yaylas in the Crimea.

Features of the structure of the I. sibirica inflorescence were interpreted differently. In particular, Chugaeva (2004) considers the upper group of flowers in I. sibirica as closed terminal florescence, and the lower - as paracladium. In our opinion, both complex monochasia - upper and lower, should be considered as axillary paracladia, as they are both covered with integumentary leaves (Skrypets \& Odintsova, 2017). This is consistent with other data on the axillary location of paracladia in members of Iridaceae (Choob, 2000; Szôllôsi, 2010). In this case, the synflorescence in I. sibirica should be considered polythelic, without apical flower or inflorescence. According to Kuznetsova et al. (1992), in I. sibirica synflorescence is an open sawdust with 1-3 paracladia, constructed as small-flowered (1-3 flowers) complex fan-shaped monochasia, with different peduncle lengths and a significant degree of polyvariance in number, location and order of flowering.

The structure of the I. sibirica flower is well studied (Szöllösi et al., 2010; Odintsova \& Skrypets, 2014), but we revealed a perigonal nectar on the inner surface of the perianth tube, which accumulates nectar and attracts pollinators such as Apis mellifera (Linnaeus, 1758) (honey bee) and Bombus bombus (Latreille, 1802) (bumble bee).

Fruit size corresponds to our previously published data for another population (Skrypets \& Odintsova, 2015). In the literature it is stated that the number of seed germs varies between 46-83 pieces (Benseytova, 2009), which is significantly less than in the fruits we studied. It was also previously found that the seed germs and seeds in the fruit are located in two rows in each nest of the ovary, attached from the base to the top of the nest to the central column, do not hang (Skrypets \& Odintsova, 2015). When studying the morphometric parameters of seeds, we find that they correspond to data from the territory of Ukraine (Sikura, 2014; Skrypets \& Odintsova, 2015). However, they are slightly smaller than according to data from the territory of Russia (length $-4-6 \mathrm{~mm}$, width $-4-5 \mathrm{~mm}$ ) (Chugaeva, 2006).

According to Rodionenko (1961), in species of the genus Iris both of these methods of opening the capsule were noted, which starts from the top of the capsule and is carried out with two types of slits (dorsal and ventral) and slit, which is carried out only through dorsal slits in the middle capsules. However, for I. sibirica, these two types of capsule opening were discovered by us for the first time.

The phytophages from the genus Ceutorrhynchus that affected flower buds and fruits were also found in coenopopulations of I. sibirica (Iridaceae) in the floodplains of Bryansk region of Russia (Mu-Za-Chin \& Shukla, 2016).

Note that according to Shvets (2005), species of the genus Iris are long-growing plants (vegetation period lasts about seven months), with stable spring-summer flowering, which lasts on average for about 20 days and fruiting, which lasts 50-80 days in the forest-steppe of Ukraine. For I. sibirica, we found a growing season of about nine months, which is slightly longer than for other species of the genus Iris.

According to Prokopchuk \& Yarmolenko (2012) and Shvets (2005) in culture conditions, in I. sibirica the coefficient of seed productivity is about $75.5 \%$, which is slightly higher than our data. The coefficient of seed productivity in our country is high and approaches the results of the study of this species in culture (75.5\%) (Shvets, 2005). These data indicate high population stability.

In the literature it is noted that the average population density of $I$. sibirica is 19-260 shoots $/ \mathrm{m}^{2}$. And also it is observed that younger populations have more individuals compared to older populations. Therefore, our data coincide with data from Russia (Mu-Za-Chin \& Shukla, 2016).

\section{Conclusion}

According to revised data, I. sibirica should be classified in the group of Euro-West Siberian, and not as a Euro-Siberian or even Eurasian species.

We found that the inflorescence of I. sibirica in the population from the botanical reserve of national importance "The Valley of the Irises" consists of 1-3 fan-shaped small-flowered monochasias. Stilodia of I. sibirica are flat, elongated, unevenly toothed, bilobed on the upper edge. We first discovered that on the inner surface of the flower tube there is a multilayer secretory tissue - perigonal nectar.

It was revealed that fruiting in I. sibirica lasts quite a long time: 23 months (60-80 days) from June to August. The coefficient of seed productivity of I. sibirica was high and quite stable, but despite the high potential and actual seed productivity in the coenopopulation there is a weak seed recovery, which is associated with high turfing and invasion of members of phytophagous genus Ceutorhynchus. Their activity dramatically reduces the maturation and dissemination of full-fledged mature seeds due to damage to flowers, capsules and seeds in them. However, the population of I. sibirica in the conditions of "The Valley of the Irises" is mature, normal, with a slight predominance of young individuals, which provides it with positive dynamics.

\section{References}

Barykina, R. P., Veselova, T. D., Deviatov, A. G., Jalilova, K. K., Ilyina, G. M., \& Chubatova, N. V. (2004). Spravochnik po botanicheskoy mikrotekhnike [Handbook of the botanical microtechniques]. Moscow University Press, Moscow (in Russian).

Beideman, I. N. (1974). Metodika izucheniya fenologii rasteniy i rastitelnykh soobshchestv [Method for studying the phenology of plants and plant communities]. Nauka, Novosibirsk (in Russian).

Benseitova, E. A., Lysyakova, N. Y., Kirpicheva, L. F. (2009). Tsitoembriologicheskie osobennosti predstaviteley roda Iris L. [Cytoembryological features of representatives of the genus Iris L.]. Actual problems of botany and ecology: International Conference of young students, Ukrainian, Kremenets, August 11-15, 2009. Publisher Textbooks and Manuals, Kremenets. Pp. 163 (in Ukrainian).

Choob, V. V. (2000). Patterns of flower and inflorescence architecture in Crocus L. (Iridaceae). Annalidi Botanica, 58, 91-104.

Chugaeva, V. N. (2006). Osobennosti reproduktivnoy biologii predstaviteley roda Iris L. [Peculiarities of the reproductive biology of some representatives of the genus Iris L.]. Bulletin of Tver State University, Series Biology and Ecology, 2, 138-143 (in Russian).

Didukh, Y. P. (Ed.). (2009). Chervona knyha Ukrayiny. Roslynnyj svit [The Red Data Book of Ukraine. Plant world]. Hlobalkonsaltynh, Kyiv (in Ukrainian).

Doronkin, V. M. (1987). Semeystvo Iridaceae - Kosatikovye. Flora Sibiri. AraceaeOrchidaceae [Family Iridaceae. Flora of Siberia. Araceae-Orchidaceae]. Nauka, Moscow (in Russian). 
Goldblatt, P., \& Manning, J. (2008). The Iris family. Natural history and classification. Timber Press, Portland.

Kharchenko, V. V., \& Naumov, S. Y. (2014). Rod Iris L. vo flore yugo-vostoka Ukrainy [The genus Iris L. in the flora of the south-east of Ukraine]. Problems and perspectives of the plant world investigations: International Scientific and Practical Conference of the young scientists, Ukrainian, Yalta, May 13-16, 2014. Publisher G. V. Kornilyev, Yalta. P. 130 (in Russian).

Kuznetsova, T., Pryakhina, N., \& Yakovlev, G. (1992). Sotsvetiya: Morfologicheskaya klassifikatsiya [Inflorescences: Morphological Classification]. Chemical-Pharmaceutical Institute, Saint Petersburg (in Russian).

Levina, R. E. (1963). K izucheniyu ritma plodonosheniya travyanistykh mnogoletnikov [To the study of the rhythm of fruiting of herbaceous perennials]. Botanical Journal, 48(10), 1512-1520 (in Russian).

Levina, R. E. (1967). Plody. Morfologiya, ekologiya, prakticheskoe znachenie [Fruit. Morphology, ecology, practical significance]. Privolzhskoe Knizhnoe Izdatelstvo, Saratov (in Russian).

Levina, R. E. (1969). O "monograficheskom" issledovanii semennoy reproduktsii nekotorykh vidov. Voprosy antekologii [About the "monographic" study of seed reproduction of certain species. Questions of antecology]. Problems of Botany, 1969, 33-34 (in Russian).

Lukash, O. V. (2010). Flora sudynnykh roslyn Skhidnoho Polissya: Sozolohichna otsinka [Flora of vascular plants of Eastern Polissya: Sociological assessment]. Kyiv, Phytosocialcenter (in Ukrainian).

Mathew, B. (1981). The Iris. Universe Books, New York.

Melnyk, V. I., Baransky, O. R., Goncharenko, V. I., Kuzyarin, O. T., \& Podorozhny, D. S. (2009). Iris sibirica L. In: Didukh, Y. P. (Ed.). Chervona knyha Ukrainy. Roslynnyi svit [Red Book of Ukraine. Flora]. Global Consulting, Kyiv. P. 132 (in Ukrainian).

Meusel, H., Jäger, E., \& Weinert, E. (1965). Vergleichende Chorologie der Zentraleuropäischen Flora. Karten. Veb Gustav Fischer Verlag, Jena.

Mosyakin, S. L., \& Fedoronchuk, M. M. (1999). Vascular plants of Ukraine. M. G. Kholodny Institute of Botany, Kyiv.

Mu-Za-Chin, V. V., \& Shukal, V. V. (2016). Kharakteristika tsenopopulyatsiy Iris sibirica L. (Iridaceae) $\mathrm{v}$ poymakh rek $\mathrm{v}$ Bryanskoy oblasti [The characteristic of Iris sibirica L. (Iridaceae) coenopopulations in river floodplains in Bryansk region]. Bulletin of Bryansk dpt. of RBS, 8, 36-43 (in Russian).

Odintsova, A., \& Skrypec, C. (2014). Novi dani shchodo zapylennia Iris sibirica L. (Iridaceae) [New data on pollinaton of Iris sibirica L. (Iridaceae)]. Studia Biologica, 8(3-4), 197-208 (in Ukrainian).

Podorozhniy, D. S. (2010). Novi mistseznakhodzhennya Iris sibirica L. v Krymu. [New locations of Iris sibirica L. in Crimea]. Current issues of botany and ecology: International Conference of young scientists. Yalta, September 21-25, 2010. Arial, Simferopol. P. 134 (in Ukrainian)

Podorozhniy, D. S. (2012). Heohrafichne poshyrennya Iris sibirica L. v Ukrajini [Geographical distribution of Iris sibirica L. in Ukraine]. Plant Introduction, 1, 29-36 (in Ukrainian).

Prokopchuk, V. M., \& Yarmolenko, T. S. (2012). Osoblyvosti nasinnyevoho rozmnozhennya kvitnykovo-dekoratyvnykh vydiv rodu Iris L. V umovakh Podillya [Features of seed reproduction of floral-decorative types of sort Iris L. in the conditions in Podillia region]. Scientific Papers of VNAU, 36, 142-148 (in Ukrainian).

Rodionenko, G. I. (1961). Rod Iris [Genus Iris]. Nauka, Moscow - Leningrad (in Russian).
Seniv, M. M., \& Tasenkevych, L. O. (2017). Novi lokalytety Iris sibirica (Iridaceae) v Lvivskiy oblasti [New localities of Iris sibirica (Iridaceae) from Lviv Region] Ukrainian Botanical Journal, 74(6), 574-577 (in Ukrainian).

Shelyag-Sosonko, Y. R. (Ed.). (1996). Chervona knyha Ukrainy. Roslynnyi svit [Red Data Book of Ukraine. Flora]. Ukrainian encyclopedia, Kyiv (in Ukrainian)

Shvets, T. A. (2005). Nasinnyeva produktyvnist vydiv rodu Iris L. za umov kultury. [Seed productivity of species in the genus Iris L. in conditions of cultivation]. Actual problems and preservation of phytosanitary issues, 2005, 145-146 (in Ukrainian).

Shynder, O. (2013). New localities of Iris sibirica in Chernihiv Polissya. Actual Problems of botany and ecology: Proceedings of the International conference of young scientists. Shcholkine, April 18-22, 2013. Phytosotsiocenter, Kyiv. P. 119.

Sikura, A. Y., \& Sikura, Y. Y. (2003). Morfolohichni osoblyvosti plodiv i nasinnya vydiv rodyny Iridaceae Lindl. [Morphological features of fruits and species in the homeland of Iridaceae Lindl.]. Scientific Bulletin of Uzhhorod University, Biology, 13, 12-24 (in Ukrainian).

Skrypec, C., \& Odintsova, A. (2015). Morfolohichna budova plodu i nasinyny Iris sibirica L. ta Gladiolus imbricatus L. u zv'yazku iz sposobamy dyseminatsii [Fruit and seed morphology in Iris sibirica L. and Gladiolus imbricatus L. in relation with the modes of dissemination]. Biological Systems, 7(1), 93-96 (in Ukrainian).

Skrypec, C., \& Odintsova, A. (2017). Morfolohichna struktura sutsvit' Gladiolus imbricatus L. ta Iris sibirica L. (Iridaceae) [Morphological structure of the inflorescence in Gladiolus imbricatus L. and Iris sibirica L. (Iridaceae)]. Studia Biologica, 11(1), 109-116 (in Ukrainian).

Szőllősi, R., Medvegy, A., Nemeth, A., Kálmán, K., \& Mihalik, E. (2010). Intrainflorescence variations in floral morphological and reproductive traits of Iris sibirica L. Acta Biologica Szegediensi, 54(2), 103-110.

Tokaryuk, A., Chorney, I., Budzhak, V., \& Volutsa, O. (2016). Poshyrennya ta ekoloho-tsenotychni osoblyvosti populyatsiy Iris sibirica L. (Iridaceae Juss) u Chernivetskiy oblasti [Distribution, ecological and coenotic features of populations of Iris sibirica L. (Iridaceae Juss) in Chernivtsi region]. Visnyk of the Lviv University, Series Biology, 74, 116-126 (in Ukrainian).

Tzvelev, N. N. (1982). Family Iridaceae Juss. In: Tzvelev, N. N. (Eds.). Flora evropeyskoy chasti SSSR [Flora of the European part of the USSR]. Moscow. Pp. 180-194 (in Russian).

Webb, D. A. (1980). Iris L. In: Flora Europaea. Alismataceae to Orchidaceae. Cambridge Univversity Press. Vol. 5. Pp. 87-92.

Yutang, Z., Noltie, H. J., \& Mathew, B. (2000). Iridaceae A. L. Jussieu. In: Wu, Z. Y., \& Raven, P. H. (Eds.). Flora of China. Vol. 24. Science Press, Beijing, and Missouri Botanical Garden Press, St. Louis. Pp. 297-313.

Zhygalova, S. V. (2014). Pivnyky bolotni (Iris pseudacorus L.) u flori Ukrainy: Khorolohiya [Yellow flag iris (Iris pseudacorus L.) in the flora of Ukraine: Chorology]. Ecology of wetlands and peatlands. P. 93 (in Ukrainian).

Zhygalova, S. V., \& Futoma, O. A. (2012). Poshyrennya vydiv rodu Iris L. (Iridaceae), zanesenykh do "Chervonoi knyhy Ukrainy" [Distribution of species of the genus Iris L. (Iridaceae) listed in the "Red Book of Ukraine"]. Flora in the Red Data Book of Ukraine. Implementation of the Global Conservation Strategy: II International Scientific Conference, Uman, October 9-12, 2012. Publisher A. V. Palivoda, Kyiv. Pp. 94-97 (in Ukrainian).

Zlobin, Y. A., Sklyar, V. G., \& Klimenko, A. A. (2013). Populyatsii redkikh vidov rasteniy: Teoreticheskie osnovy i metodika izucheniya [Populations of rare plant species: Theoretical foundations and research methods]. University Book, Sumy (in Russian). 